\title{
Ploidy, water, and nitrogen effects on Russian wildrye chemical composition
}

\author{
J.F. KARN, A.B. FRANK, J.D. BERDAHL, AND W.W. POLAND
}

Authors are Research Animal Scientist, Plant Physiologist, and Plant Geneticist, USDA, Agricultural Research Service, Northern Great Plains Research laboratory, P. O. Box 459, Mandan, N.D. 58554, and Ruminant Nutritionist, North Dakota State University, Dickinson Research Extension Center, Dickinson, N.D.58601, respectively.

\section{Abstract}

Russian wildrye [Psathyrostachys juncea (Fisch.) Nevski], a cool-season introduced bunchgrass, offers producers an alternative to crested wheatgrass [Agropyron desertorum (Fisch. ex Link) Schultes] for spring and fall grazing in the Northern Great Plains. Tetraploid Russian wildrye with improved seedling establishment may offer even greater potential for seasonal grazing. This study investigates how the concentrations of some nutritive quality components in leaf, stem, and inflorescence tissue of diploid and tetraploid Russian wildrye were affected by growing season water ( 50 and $\mathbf{1 5 0 \%}$ of average precipitation) and fertilizer (10 and $\left.134 \mathrm{~kg} \mathrm{~N} \mathrm{ha}^{-1}\right)$. Plants were sampled at vegetative, boot, anthesis, and anthesis plus 10-day stages of maturity in 1994, 1995, and 1996. Tetraploid plants had slightly $(\mathbf{P}<\mathbf{0 . 0 5})$ less crude protein (CP) in leaf, stem and inflorescence tissue than diploid plants. Plants grown at the $50 \%$ water treatment had higher CP and in vitro dry matter digestibility (IVDMD), and lower acid detergent fiber (ADF) and neutral detergent fiber (NDF) in leaf and inflorescence tissue, while in stem tissue only $\mathrm{CP}$ was affected by the growing season water treatment. Nitrogen fertilizer resulted in greater CP and IVDMD and lower $A D F$ and NDF in all 3 plant tissues. Maturity affects were consistent over leaf, stem and inflorescence tissue, with $\mathrm{CP}$ and IVDMD declining and ADF and NDF increasing as plants matured. There were some differences in nutritive quality components between diploid and tetraploid plants, but overall their qualities were comparable and quite good. Crude protein at all stages of maturity in leaf and inflorescence tissue would have been adequate for most classes of beef cattle, while stem tissue CP would have only been adequate for lower producing animals.

Key Words: diploid, tetraploid, stage of maturity, rain shelter, forage quality

Mention of a trade name is solely to identify materials used and does not constilute endorsement by the U.S. Department of Agriculture. The authors wish to thank Dr. Gary V. Richardson and Dr. Mark West for advice with statistical procedures.

Acid detergent fiber analyses for this research was partially funded by a grant from the North Dakota Board of Agricultural Research.

U. S. Department of Agriculture, Agriculture Research Service, Northern Plains Area, is an equal opportunity/affirmative action employer and all agency services are available without discrimination.

Manuscript accepted 16 Dec. 2003

\section{Resumen}

El "Russian wildrye" [Psathyrostachys juncea (Fisch.) Nevski], es una especie introducida, amacollada y de estación fría que ofrece a los productores una alternativa del "Crested wheatgrass" [Agropyron desertorum (Fisch. ex Link) Schultes] para el apacentamiento en primavera y otoño en las Grandes Planicies del Norte. El "Russian wildrye" tetraploide, con capacidad mejorada de establecimiento, puede ofrecer aun un mayor potencial para el apacentamiento estacional. Este estudio investigó como la concentración de algunos componentes de la calidad nutritiva de los tejidos de hoja, tallo e inflorescencia del "Russian wildrye" diploide y tetraploide son afectados por la cantidad de agua (50 y $150 \%$ de la precipitación promedio) y de fertilizante (10 y 134 kg N ha ${ }^{-1}$ ) recibidos en la estación de crecimiento. Durante 1994, 1995 y 1996 las plantas se muestrearon en las etapas de crecimiento vegetativo, embuche, antesis y antesis más $\mathbf{1 0}$ días. Las plantas tetraploides tuvieron ligeramente menos $(\mathrm{P}<0.05)$ proteína cruda (CP) en hoja, tallo e inflorescencia que las plantas diploides. Las plantas que crecieron al nivel de $50 \%$ de la precipitación promedio tuvieron mas alto contenido de CP y digestibilidad in vitro de la materia seca (IVDMD) y contenidos más bajos de fibra ácido detergente (ADF) y fibra neutro detergente (NDF) en la hoja e inflorescencia, mientras que en los tallos solo la CP fue afectada por el tratamiento de agua. La fertilización nitrogenada produjo mayores contenidos de CP y IVDMD y menores niveles de ADF y NDF, esto fue similar para los tres tejidos analizados. Los efectos de la madurez fueron consistentes en los tejidos de hoja, tallo e inflorescencia y a medida que la planta maduró y el contenido de CP y IVDMD disminuyeron y la ADF y NDF aumentaron. Hubo algunas diferencias en los componentes de la calidad nutritiva entre las plantas diploides y tetraploides, pero en general sus calidades fueron comparables y muy buenas. La CP de la hoja e inflorescencia en todas las etapas de madurez hubieran sido adecuados para la mayoría de las clases de ganado mientras que el CP de los tallos hubiera sido solo adecuado para animales de baja productividad.

In the Northern Great Plains there are few alternatives to crested wheatgrass [Agropyron desertorum (Fisch. ex Link) Schultes] for early season grazing. Russian wildrye [Psathyrostachys juncea (Fisch.) Nevski] is a potentially valuable, but currently under utilized cool-season bunchgrass introduced to the United States from the former U.S.S.R. in 1927 (Johnson and Nichols 1970). Its use has been limited by poor seedling vigor and related 
establishment problems (Lawrence 1963). Tetraploid Russian wildrye germplasm has improved seedling emergence, larger plant cells, and longer and wider leaves compared to diploid cultivars (Berdahl and Barker 1991, Berdahl and Ries 1997). Changes in leaf morphology may affect plant nutritive value. Tetraploid perennial ryegrass (Lolium perenne L.) cultivars were more digestible and had higher concentrations of crude protein (CP) and lower concentrations of neutral detergent fiber (NDF) than diploid cultivars (Jensen et al. 2003).

The effects of drought on forage quality have been inconsistent. Water stress in crested wheatgrass [Agropyron cristatum (L.) Beauv.], smooth bromegrass (Bromus inermis Leyss.), and Altai wildrye [Leymus angustus (Trin.) Pilger], increased the rate of seasonal decline in nitrogen (N) and phosphorus, but decreased the seasonal decline in digestibility, by reducing the rate of increase in acid detergent fiber (ADF) and lignin (Bittman et al. 1988). In kleingrass (Panicum coloratum L.), a warm-season perennial, both stem and leaf IVDOM decreased as water stress increased, even though leaf percentage increased (Pitman et al. 1981). Water stressed kleingrass had an increased proportion of cell wall components and increased lignification (Pitman et al. 1983). Water stress had a positive effect on orchardgrass (Dactylis glomerata L.) and perennial ryegrass quality by increasing $\mathrm{CP}$ and digestible neutral detergent fiber (Jensen et al. 2003).

Nitrogen fertilizer can also affect plant nutritive value. In vitro organic matter digestibility (IVOMD) of Russian wildrye was increased by fertilizing with $200 \mathrm{~kg} \mathrm{~N}$ $\mathrm{ha}^{-1}$, and the effect was evident seasonlong except at mid-May and early September sampling dates (Lawrence and Knipfel 1981). Adding $\mathrm{N}$ fertilizer increased Russian wildrye whole plant $\mathrm{N}$ at all dates except mid-May (Lawrence et al. 1982).

Plant parts may differ in nutritive quality and be differentially affected by plant maturity. A decline in timothy (Phleum pretense L.), orchardgrass, and smooth bromegrass IVDMD as maturity advanced was observed in all plant portions (Pritchard et al. 1963), but the rate of decline was greater in stems than leaves (Pritchard et al. 1963, Mowat et al. 1965). Immature timothy, orchardgrass, and smooth bromegrass stems were higher in IVDMD than leaves, and these 3 grasses showed little species difference in leaf and stem CP (Mowat et al. 1965). From the boot stage on, $\mathrm{CP}$ was higher in smooth bromegrass leaves than stems (Kilcher and Troelsen 1973). At maturity smooth bromegrass (Kilcher and Troelsen 1973) and Russian and Altai wildrye (Kilcher 1975) stem digestibility had declined to a much lower level than leaf tissue. Kilcher and Troelsen (1973) also reported that cell wall lignin increased more in stems than leaves with advance in maturity.

Stem IVDMD differences (24\%) between orchardgrass cultivars were greater than leaf $(7 \%)$ tissue differences (Buxton and Marten 1989). In smooth bromegrass, 'Rebound' stems were $12 \%$ more digestible than 'Barton', but Barton leaf tissue was $6 \%$ more digestible than Rebound (Buxton and Marten 1989). Among 5 cool-season grass species, differences appeared to be related more to herbage yield and morphology than to leaf and stem quality (Baron et al. 2000). Relative differences in leaf blade NDF, $\mathrm{ADF}$ and $\mathrm{CP}$ of meadow brome (Bromus riparius $\mathrm{Rehm}$.), smooth bromegrass and a meadow brome $x$ smooth bromegrass hybrid were related more to species than to stage of maturity, while stem quality differed among species and stage of maturity (Ferdinandez and Coulman 2001).

The lack of nutritive quality data for the relatively new tetraploid Russian wildrye, as well as the need to better understand the effect of $\mathrm{N}$ fertilizer and drought stress on the quality of this species precipitated the research. Drought is a common problem in the Great Plains and fertilizing with $\mathrm{N}$ is a common management practice. Thus, objectives of the research were to determine the effect of ploidy, water, and fertilizer $\mathrm{N}$ on the nutritive quality of Russian wildrye leaf, stem, and inflorescence tissue harvested at 4 stages of maturity.

\section{Materials and Methods}

In 1993, diploid and tetraploid entries of Russian wildrye were seeded under a movable rain shelter located near Mandan, N.D. $\left(46^{\circ} 48^{\prime} \mathrm{N}, 100^{\circ} 55^{\prime} \mathrm{W}\right)$. During precipitation events a $12.1-\mathrm{m} \times 30.3-\mathrm{m}$ shelter automatically covered the plot area (Ries and Zachmeier 1985). Plots were irrigated during the growing season with an overhead sprinkler system attached inside the shelter. Entries were grown in 8-row plots (3.6-m length, $0.33-\mathrm{m}$ between rows) on Parshall fine sandy loam soils (coarseloamy, mixed superactive, frigid, pachic Haplustrolls). Entries were the diploid cultivar Vinall, which has been used as a standard in many Russian wildrye studies, and a tetraploid entry which was a bal. anced composite of 6 populations representative of tetraploid germplasm in the Mandan breeding program (Frank and Berdahl 2001).

There were 4 replicates of each entry arranged in a split-split plot design. Watt treatments were main plots, with $\mathrm{N}$ levels as subplots and entries as sub-subplots. Water treatments provided 50 and $150 \%$ of the long-term average monthly precipi. tation for April through October, at Mandan. Long-term averages ( $30 \mathrm{yr}$ ) wert based on precipitation levels, in $\mathrm{mm}$, of 38 (April), 55 (May), 85 (June), 61 (July), 4: (August), 38 (September), and 24 (October) (Frank and Berdahl 1999). Treatment levels were achieved by weekly watering. Each year plots were exposed tt natural precipitation from November through March. Nitrogen treatments applied in April of each year consisted of 10 and $134 \mathrm{~kg} \mathrm{~N} \mathrm{ha}^{-1}$ from ammonium nitrate. Water and $\mathrm{N}$ treatments were init ated in 1993, to ensure that plants wer acclimated to their respective treatmen before data collection was initiated i 1994. The study contained a total of 3 . plots from 4 replications of 2 ploidy le els, 2 water levels, and $2 \mathrm{~N}$ levels. So water potential measurements taken on weekly basis from these plots have bee published previously (Frank and Berdah 2001).

Forage samples were hand-clipped $\mathrm{at}$ approximately $5-\mathrm{cm}$ stubble height fron plots for nutritive quality analysis at the vegetative, boot, anthesis, and anthesi plus 10-day stages of maturity, in 1994 1995, and 1996. Forages developed at dif ferent rates each year due to variation in accumulated growing degree days; thus sampling dates were not consistent amon years. In 1994, samples were clipped on 4 16, and 31 May, and 14 June; in 199. samples were clipped on 10 and $22 \mathrm{Ma}$ and 6 and 21 June; and in 1996, sample were clipped on 17 and 28 May and 1. and 26 June. Within years, forage sample were clipped from a different portion 0 the plot at each sampling date. I September, all plots were clipped to a sinilar height to minimize any possible pla effects the following year.

After clipping, samples were rinsed in distilled water to remove any contaminat ing soil, and dried at $55^{\circ} \mathrm{C}$ in a forced-ail oven. All samples were ground through 1 -mm screen before analysis. Samples col lected at anthesis and anthesis plus 10-day stages of maturity were separated into leaf stem and inflorescence tissue before bein 
ground. Forage samples obtained at vegetative and boot stages of maturity consisted mainly of leaf tissue and were not separated. Samples were analyzed for nitrogen using a Carlo Erba Model NA 1500 series 2 nitrogen/carbon/sulphur analyzer (CE Elantech, Inc., Lakewood, N.J. 08701). Crude protein was calculated by multiplying nitrogen by 6.25 . Acid detergent fiber, neutral detergent fiber (NDF), and in vitro true digestibility were determined according to Goering and Van Soest (1970). An ANKOM fiber analyzer (ANKOM Technology Corporation, Fairport, N.Y.) was used to facilitate measuring $\mathrm{ADF}$, and NDF in forage samples and forage residue following a 48-hr in vitro fermentation, for IVDMD (Vogel et al. 1999).

Data were analyzed using the SAS MIXED procedure (SAS Inst., Inc. 1996) with ploidy, water, $\mathrm{N}$ level and harvest date, fixed and replication, replication $x$ water level, and replication $\mathrm{x}$ water $\mathrm{x}$ ploidy $\mathrm{x} \mathrm{N}$ level considered random. Years were treated as repeated measures. Least squares means for ploidy, water, and $\mathrm{N}$ levels were separated by an F-test and means for harvest date were separated by the SAS PDIFF option. Data comparisons were considered significant at $\mathrm{P}<0.05$.

\section{Results}

The F-values and statistical probabilities for main effects and interactions are summarized for leaf, stem, and inflorescence tissue in Table 1. The F-values tended to be of much greater magnitude for main effects than interaction effects.

\section{Ploidy Level}

Crude protein and NDF were slightly higher in leaf tissue from diploid compared to tetraploid plants, while ADF and

Table 2. The effect of ploidy level on crude protein (CP), neutral detergent fiber (NDF), acid detergent fiber (ADF), and in vitro digestible dry matter (IVDMD) in leaf, stem, and inflorescence tissues averaged over water level, nitrogen level, and harvest date.

\begin{tabular}{lcccc}
\hline \hline Ploidy level & CP & NDF & ADF & IVDMD \\
\hline Leaf & $\cdots$ & & & \\
Diploid & $223^{\mathrm{a}}$ & $548^{\mathrm{a}}$ & 288 & 859 \\
Tetraploid & $210^{\mathrm{b}}$ & $537^{\mathrm{b}}$ & 289 & 860 \\
$\quad \mathrm{SE}$ & 5.7 & 2.6 & 1.2 & 1.5 \\
Stem & & & & \\
Diploid & $102^{\mathrm{a}}$ & 724 & 438 & 600 \\
Tetraploid & $94^{\mathrm{b}}$ & 723 & 444 & 588 \\
$\quad$ SE & 4.5 & 5.0 & 4.6 & 6.9 \\
Inflorescence & & & & \\
Diploid & $184^{\mathrm{a}}$ & $612^{\mathrm{b}}$ & $320^{\mathrm{b}}$ & $660^{\mathrm{a}}$ \\
Tetraploid & $167^{\mathrm{b}}$ & $631^{\mathrm{a}}$ & $351^{\mathrm{a}}$ & $633^{\mathrm{b}}$ \\
$\quad$ SE & 2.6 & 2.8 & 3.8 & 4.2 \\
\hline
\end{tabular}

${ }^{1}$ Means within a tissue type and chemical component with different superscripts differ at $P<0.05$.

IVDMD were not affected by ploidy level (Table 2). There was a significant $(\mathrm{P}<$ 0.01 ) interaction for leaf $\mathrm{CP}$ between ploidy and $\mathrm{N}$ fertilizer levels (Table 1). Although diploid leaf tissue was higher in $\mathrm{CP}$ at both $\mathrm{N}$ fertilizer levels, there was much less difference between diploid and tetraploid CP levels at the high $\mathrm{N}(134 \mathrm{~kg}$ $\mathrm{N} \mathrm{ha}{ }^{-1}$ ) treatment (Fig. 1 A). A significant $(P<0.01)$ interaction between ploidy level and harvest date occurred for NDF in leaf tissue (Table 1). Tetraploid leaf tissue was clearly lower in NDF at the first 2 harvest dates (vegetative and boot stages) while at the last 2 harvest dates there was little difference in NDF between diploid and tetraploid plants (Fig. 2C). Stem tissue from diploid plants was also higher in $\mathrm{CP}$ than tetraploid plants while IVDMD, NDF, and ADF concentrations in stem tissue were not affected by ploidy level (Table 2).

Crude protein in diploid inflorescence tissue was higher than in tetraploid, which is consistent with leaf and stem tissue, but NDF in diploid inflorescence was some- what lower than tetraploid, the reverse of leaf tissue NDF (Table 2). Significant $(\mathrm{P}<$ 0.01 ) interactions occurred between ploidy level and harvest date for CP and NDF in inflorescence tissue (Table 1). Crude protein was higher at both harvest dates (anthesis and anthesis plus 10-day) for diploid inflorescence tissue, but the difference between ploidy levels was much greater at the later harvest date (Fig. 2D). Neutral detergent fiber in diploid inflorescence tissue was only slightly lower than tetraploid at anthesis (earliest harvest date for inflorescence), but at the later harvest date diploid NDF was about $30 \mathrm{~g} \mathrm{~kg}^{-1}$ less than tetraploid inflorescence tissue (Fig. $2 E$ ). Diploid Russian wildrye inflorescence tissue had lower ADF and higher IVDMD than tetraploid inflorescence (Table 2).

\section{Water Treatment}

Plants from the $50 \%$ water treatment had higher leaf tissue CP, and IVDMD and lower ADF and NDF than plants grown at the $150 \%$ water treatment (Table

Table 1. Russian wildrye leaf, stem and inflorescence F-values and probabilities for main effects and interactions.

\begin{tabular}{|c|c|c|c|c|c|c|c|c|c|c|c|c|}
\hline & \multicolumn{4}{|c|}{ 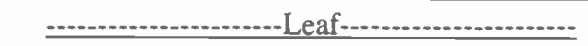 } & \multicolumn{4}{|c|}{ n..................-Stem-.................... } & \multicolumn{4}{|c|}{$\ldots$} \\
\hline & $\overline{\mathrm{CP}}$ & IVDMD & ADF & NDF & $\mathrm{CP}$ & IVDMD & $\mathrm{ADF}$ & $\mathrm{NDF}$ & $\mathrm{CP}$ & IVDMD & ADF & NDF \\
\hline Ploidy (P) & $24.4^{* *}$ & 0.6 & 0.1 & $23.9 * *$ & $7.2^{*}$ & 3.0 & 1.8 & 0.0 & $26.9 * *$ & $38.3 * *$ & $32.3 * *$ & $23.4 * *$ \\
\hline Nitrogen $(\mathrm{N})$ & $487.6^{* *}$ & $41.2 * *$ & $115.6^{* *}$ & $149.1 * *$ & $196.4 * *$ & $9.4 * *$ & $9.7^{* *}$ & $23.9 * *$ & $51.2 * *$ & $31.6 * *$ & $17.2 * *$ & $42.3 * *$ \\
\hline Water (W) & $41.7^{* *}$ & $55.1^{* *}$ & $95.2^{* *}$ & $65.0^{* *}$ & $67.2 * *$ & 0.2 & 4.4 & 4.8 & $24.8^{*}$ & $47.0^{* *}$ & $46.0^{* *}$ & $72.8^{* *}$ \\
\hline$P \times W$ & 4.0 & 0.0 & 0.0 & 1.6 & 0.2 & 0.1 & $4.3^{*}$ & 0.0 & 0.6 & 0.0 & 2.0 & 0.2 \\
\hline $\mathrm{P} \times \mathrm{N}$ & $7.8^{* *}$ & 3.4 & 3.5 & $5.9^{*}$ & 1.3 & 0.3 & 0.2 & 0.3 & 0.1 & 0.4 & $5.3^{*}$ & 1.3 \\
\hline $\mathrm{W} \times \mathrm{N}$ & $23.7 * *$ & 0.6 & 2.6 & $4.5^{*}$ & 0.8 & 0.2 & 1.0 & 0.4 & 3.3 & 0.4 & 0.3 & 0.1 \\
\hline$P \times W \times N$ & 2.5 & 2.0 & 1.8 & 1.5 & $10.6^{* *}$ & 0.2 & $4.6^{*}$ & 0.1 & 4.1 & 1.4 & 1.5 & 0.0 \\
\hline Harvest date (HD) & $503.6^{* *}$ & $802.4^{* *}$ & $806.2^{* *}$ & $648.4^{* *}$ & $87.6 * *$ & $240.2^{* *}$ & $40.5^{* *}$ & $120.8^{* *}$ & $173.8^{* *}$ & $638.5^{* *}$ & $76.9^{* *}$ & $251.8^{* *}$ \\
\hline $\mathrm{PxHD}$ & 1.2 & 1.4 & 1.2 & $3.9^{* *}$ & 0.1 & 0.1 & 2.8 & $3.9 *$ & $10.0 * *$ & $5.1^{*}$ & 0.3 & $22.7^{* *}$ \\
\hline $\mathrm{W} \times \mathrm{HD}$ & 0.2 & $8.6^{* *}$ & $3.8^{* *}$ & $2.9^{*}$ & 3.4 & 0.4 & 0.1 & 0.0 & 1.5 & 2.8 & 1.6 & 1.2 \\
\hline $\mathrm{N} \times \mathrm{HD}$ & $6.0^{* *}$ & $5.9 * *$ & $5.7 * *$ & $6.7^{* *}$ & $5.1^{*}$ & $4.3^{*}$ & 0.4 & 0.1 & 0.1 & 0.2 & $4.0^{*}$ & 1.1 \\
\hline $\mathrm{P} \times \mathrm{N} \times \mathrm{HD}$ & 1.5 & 0.3 & 0.2 & 0.4 & 1.5 & 0.0 & 0.1 & 0.7 & 0.0 & 0.9 & 0.8 & 3.3 \\
\hline
\end{tabular}

${ }^{*, * *}$ Indicate significance at the 0.05 and 0.01 levels of probability, respectively. 


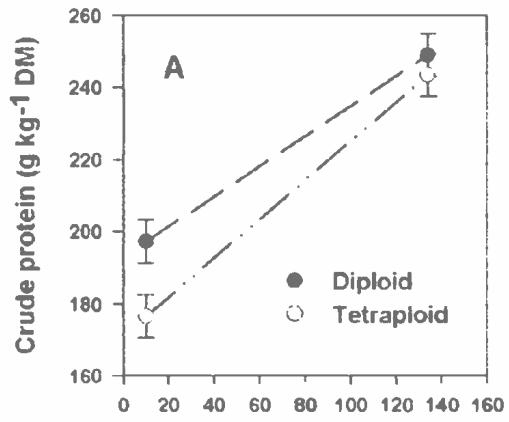

Nitrogen fertilizer rate $\left(\mathrm{kg} \mathrm{N}^{\mathrm{N}} \mathrm{ha}^{-1}\right)$

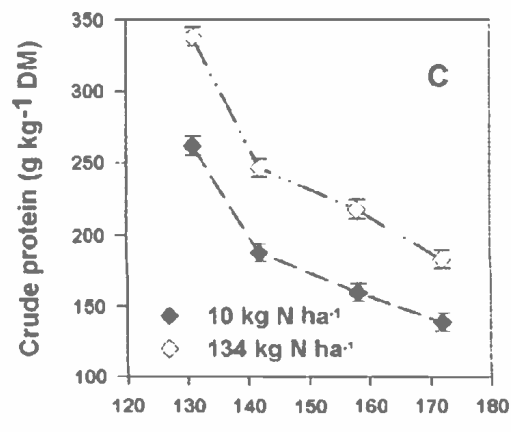

Harvest date (DOY)

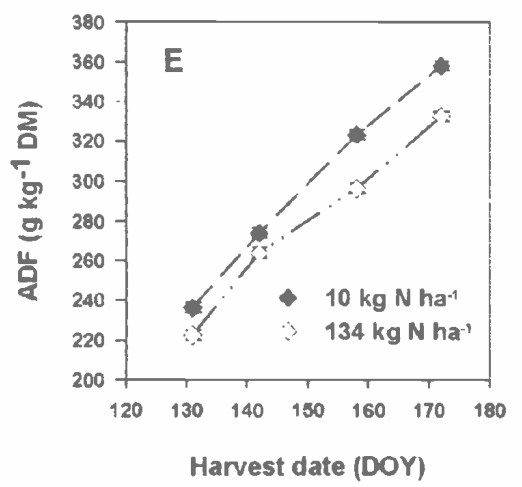

Fig. 1. Leaf tissue interaction effects of (A) nitrogen fertilizer and ploidy on crude protein, (B) nitrogen fertilizer and water on crude protein, (C) nitrogen fertilizer and harvest date on crude protein, (D) nitrogen fertilizer and harvest date on IVDMD (E) nitrogen fertilizer and harvest date on ADF, and (F) nitrogen fertilizer and harvest date on NDF.

$3)$. There was a significant $(P<0.01)$ interaction for leaf $\mathrm{CP}$ between water and $\mathrm{N}$ fertilizer levels (Table 1). Leaf tissue $\mathrm{CP}$ was higher in plants grown under the $50 \%$ water treatment at both $\mathrm{N}$ fertilizer treatments, but the difference was much greater at the $10 \mathrm{~kg} \mathrm{~N} \mathrm{ha}^{-1}$ level than at the $134 \mathrm{~kg} \mathrm{~N} \mathrm{ha}^{-1}$ level (Fig. 1B). There were also interactions between water level and harvest date for leaf IVDMD and ADF (Table 1). At the earliest harvest dates IVDMD differed little between 50 and $150 \%$ water treatments, but at the last 2 harvest dates IVDMD was clearly higher for plants grown at the $50 \%$ water treatment (Fig. 2A). Leaf ADF from plants grown at the $150 \%$ water treatment was slightly higher than $50 \%$ water treatment plants at the first 2 harvest dates while levels were more than $20 \mathrm{~g} \mathrm{~kg}^{-1}$ higher at the last harvest date (Fig. 2B).

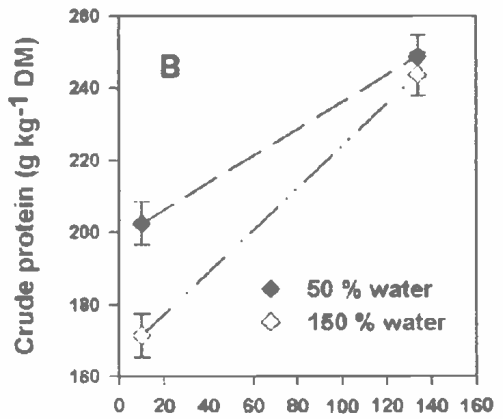

Nitrogen fertilizer rate ( $\mathrm{kg} \mathrm{N}^{\mathrm{N}} \mathrm{a}^{-1}$ )
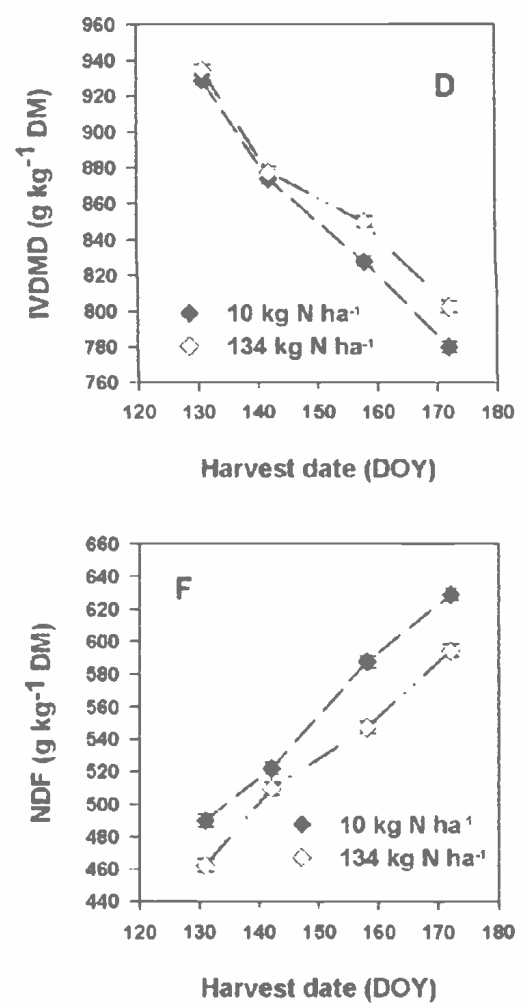

Stem tissue quality was less affected by growing season water levels than leaf tissue; however, stem tissue $\mathrm{CP}$ was higher in plants grown at the $50 \%$ water treatment (Table 3). All 4 nutritive quality components in inflorescence tissue were affected by growing season water, with the $50 \%$ water treatment having the highest $\mathrm{CP}$, and IVDMD, and the lowest ADF and NDF. Although leaf, stem and inflorescence quality components were not statistically compared, leaf tissue appears to have about twice the $C P, 30 \%$ more IVDMD, $50 \%$ less $\mathrm{ADF}$ and $35 \%$ less NDF, than stem tissue. Inflorescence tissue was closest to leaf tissue in CP and $\mathrm{ADF}$, intermediate between leaf and stem in NDF and closer to stem tissue in IVDMD.

\section{Nitrogen Fertilizer}

Fertilizing Russian wildrye with $134 \mathrm{~kg}$ $\mathrm{N} \mathrm{ha}^{-1}$ substantially increased leaf $\mathrm{CP}$ and slightly increased IVDMD, while moderately reducing leaf $\mathrm{ADF}$ and NDF, compared to plants fertilized with $10 \mathrm{~kg} \mathrm{~N}$ ha (Table 4). However, there were significant $(\mathrm{P}<0.01)$ interactions between $\mathrm{N}$ fertilizer level and harvest date for CP, IVDMD, ADF, and NDF in leaf tissue (Table 1). The rates of decline in leaf tissue $\mathrm{CP}$ were much steeper between the first and second harvest dates than between the other harvest dates and the rates of decline were slightly different for the $134 \mathrm{~kg} \mathrm{~N} \mathrm{ha}^{-1}$ and the $10 \mathrm{~kg} \mathrm{~N} \mathrm{ha}^{-1}$ treatments (Fig. 1C). Differences between $\mathrm{N}$ levels for IVDMD (Fig. 1D), ADF (Fig. 1E), and NDF (Fig. 1F) were less pronounced at the earlier 2 harvest dates than at the last 2 harvests, with IVDMD being consistently higher and ADF and NDF consistently lower for the $134 \mathrm{~kg} \mathrm{~N} \mathrm{ha}^{-1}$ treatment. Nitrogen fer-

Table 3. The effect of water level on crude protein (CP), neutral detergent fiber (NDF), acid detergent fiber (ADF), and in vitro digestible dry matter (IVDMD) in leaf, stem, and inflorescence fissues averaged over ploidy level, nitrogen level, and harvest date. ${ }^{1}$

\begin{tabular}{|c|c|c|c|c|}
\hline Water level & $\mathrm{CP}$ & NDF & $\mathrm{ADF}$ & IVDMD \\
\hline & ------ & ------- & - - - & --.--- \\
\hline \multicolumn{5}{|l|}{ Leaf } \\
\hline $50 \%$ of average & $226^{\mathrm{a}}$ & $533^{\mathrm{b}}$ & $280^{\mathrm{b}}$ & $867^{\mathrm{a}}$ \\
\hline $150 \%$ of average & $208^{b}$ & $552^{\mathrm{a}}$ & $297^{\mathrm{a}}$ & $852^{b}$ \\
\hline $\mathrm{SE}$ & 5.7 & 2.6 & 1.2 & 1.5 \\
\hline \multicolumn{5}{|l|}{ Stem } \\
\hline $50 \%$ of average & $110^{\mathrm{a}}$ & 717 & 434 & 592 \\
\hline $150 \%$ of average & $86^{b}$ & 729 & 448 & 595 \\
\hline SE & 4.5 & 5.0 & 4.9 & 6.9 \\
\hline \multicolumn{5}{|l|}{ Inflorescence } \\
\hline $50 \%$ of average & $186^{\mathrm{a}}$ & $604^{b}$ & $317^{b}$ & $662^{\mathrm{a}}$ \\
\hline $150 \%$ of average & $166^{b}$ & $638^{a}$ & $354^{\mathrm{a}}$ & $631^{b}$ \\
\hline $\mathrm{SE}$ & 2.8 & 2.8 & 3.8 & 4.2 \\
\hline
\end{tabular}

${ }^{1}$ Means within a tissue type and chemical component with different superscripts differ at $P<0.05$. 

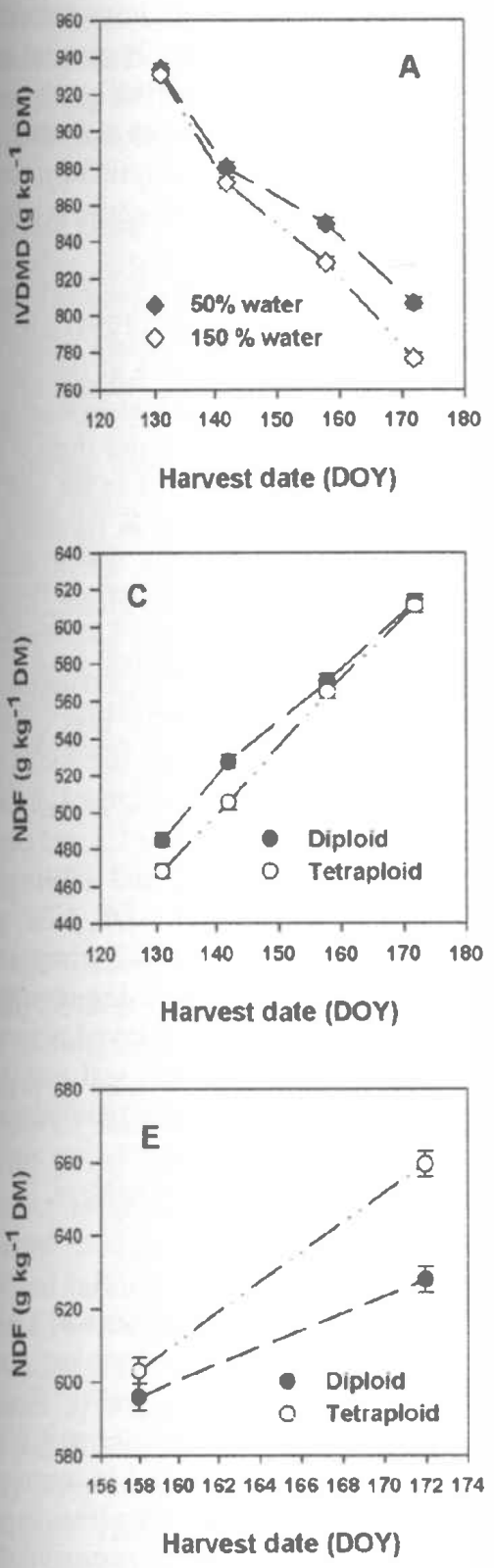

Fig. 2. Interaction effects of (A) water and harvest date on leaf IVDMD, (B) water and harvest date on leaf $\mathrm{ADF},(\mathrm{C})$ ploidy and harvest date on leaf $\mathrm{NDF}$, (D) ploidy and harvest date on inflorescence tissue crude protein, and $(E)$ ploidy and harvest date on inflorescence tissue NDF.

tilizer treatments had similar affects on quality components in stem and inflorescence tissue, and there were few significant interactions involving $\mathrm{N}$ fertilizer levels. Crude protein values in stem and inflorescence tissue from plants fertilized with $134 \mathrm{~kg} \mathrm{~N} \mathrm{ha}^{-1}$ were 119 and $188 \mathrm{~g}$ $\mathrm{kg}^{-1}$ compared to 78 and $163 \mathrm{~g} \mathrm{~kg} \mathrm{k}^{-1}$, respectively, in plants fertilized with 10 $\mathrm{kg} \mathrm{Nha}{ }^{-1}$.

\section{Harvest Date}

Leaf tissue $\mathrm{CP}$ declined among the 4 harvest dates, from $300 \mathrm{~g} \mathrm{~kg}^{-1}$ at the vegetative stage (first harvest date) to $161 \mathrm{~g} \mathrm{~kg}^{-1}$ at the anthesis plus 10-day stage (last harvest date; Table 5). Results were also consistent among the 4 harvest dates for leaf
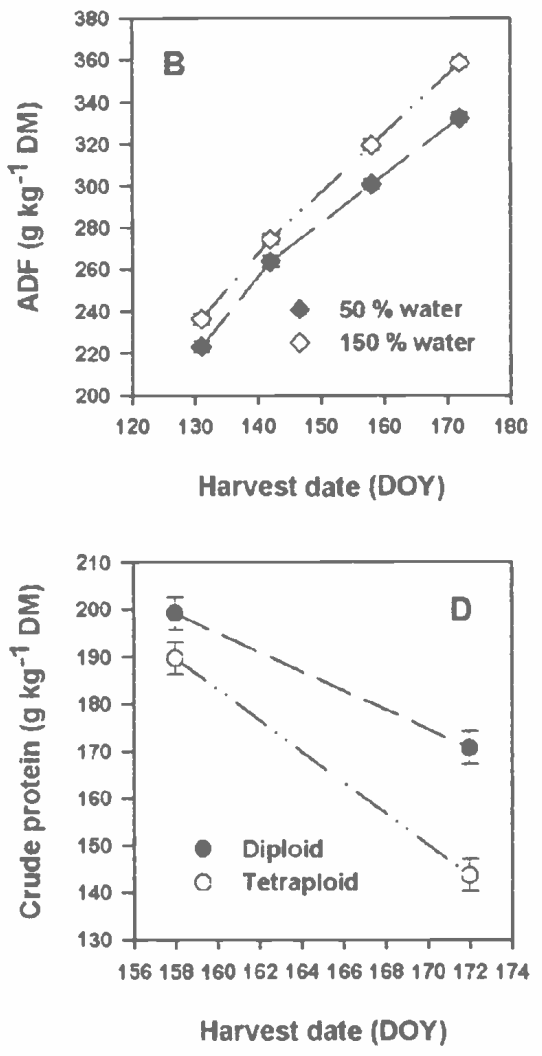

\section{Discussion}

\section{Ploidy Level}

Crude protein levels in leaf and inflorescence tissue were adequate to meet the $\mathrm{CP}$ requirements of most classes of beef cattle (NRC 1996), but stem tissue was marginal to deficient in $\mathrm{CP}$ for young rapidly growing cattle. Diploid Russian wildrye plants had slightly higher CP in leaf, stem and inflorescence tissue than tetraploid plants, but other quality components in leaf and stem tissue were minimally affected by ploidy level. Steers grazing diploid and tetraploid Russian wildrye strains in a cafeteria-style test showed little preference between ploidy levels, with the exception of 1 season out of 3 when steers did eat immature tetraploid heads more readily than diploids (Lawrence et al. 1990), which would seem to differ with our quality data. Since improvement in seedling vigor was the primary selection criteria for the tetraploid germplasm (Berdahl and Ries 1997), it is fortunate that nutritive quality was not adversely affected in the breeding and selection process.

Table 4. The effect of nitrogen level on crude protein (CP), neutral detergent fiber (NDF), acid detergent fiber (ADF), and in vitro digestible dry matter (IVDMD) in leaf, stem, and inflorescence tissues averaged over ploidy level, water level, and harvest date. ${ }^{1}$

\begin{tabular}{lcccc}
\hline \hline Nitrogen level & CP & NDF & ADF & IVDMD \\
\hline Leaf & & & & \\
\hline $10 \mathrm{~kg} \mathrm{ha}^{-1}$ & $187^{\mathrm{b}}$ & $557^{\mathrm{a}}$ & $298^{\mathrm{a}}$ & $853^{\mathrm{b}}$ \\
$134 \mathrm{~kg} \mathrm{ha}^{-1}$ & $246^{\mathrm{a}}$ & $528^{\mathrm{b}}$ & $279^{\mathrm{b}}$ & $866^{\mathrm{a}}$ \\
$\mathrm{SE}$ & 5.7 & 2.6 & 1.2 & 1.5 \\
$\underline{\text { Stem }}$ & & & \\
$10 \mathrm{~kg} \mathrm{ha}$ & & $737^{\mathrm{a}}$ & $449^{\mathrm{a}}$ & $584^{\mathrm{b}}$ \\
$134 \mathrm{~kg} \mathrm{ha}^{-1}$ & $78^{\mathrm{b}}$ & $709^{\mathrm{b}}$ & $433^{\mathrm{b}}$ & $604^{\mathrm{a}}$ \\
$\mathrm{SE}$ & $119^{\mathrm{a}}$ & 5.0 & 4.5 & 6.9 \\
$\underline{\text { Inflorescence }}$ & 4.5 & & & \\
$10 \mathrm{~kg} \mathrm{ha}^{-1}$ & $163^{\mathrm{b}}$ & $634^{\mathrm{a}}$ & $347^{\mathrm{a}}$ & $634^{\mathrm{b}}$ \\
$134 \mathrm{~kg} \mathrm{ha}^{-1}$ & $188^{\mathrm{a}}$ & $608^{\mathrm{b}}$ & $324^{\mathrm{b}}$ & $659^{\mathrm{a}}$ \\
$\mathrm{SE}$ & 2.6 & 2.8 & 3.9 & 4.2 \\
\hline
\end{tabular}

${ }^{1}$ Means within a tissue type and chemical component with different superscripts differ at $P<0.05$. 
Table 5. The effect of maturity on crude protein (CP), neutral detergent fiber (NDF), acid detergent fiber (ADF), and in vitro digestible dry matter (IVDMD) in leaf, stem, and inflorescence tissues averaged over ploidy, water, and nitrogen levels. ${ }^{1}$

\begin{tabular}{lcccc}
\hline \hline Maturity stage & CP & NDF & ADF & IVDMD \\
\hline Leaf & -1 & & & \\
Vegetative & $300^{\mathrm{a}}$ & $476^{\mathrm{d}}$ & $230^{\mathrm{d}}$ & $932^{\mathrm{a}}$ \\
Boot & $217^{\mathrm{b}}$ & $516^{\mathrm{c}}$ & $269^{\mathrm{c}}$ & $876^{\mathrm{b}}$ \\
Anthesis & $188^{\mathrm{c}}$ & $567^{\mathrm{b}}$ & $310^{\mathrm{b}}$ & $839^{\mathrm{c}}$ \\
Anthesis + 10 day & $161^{\mathrm{d}}$ & $612^{\mathrm{a}}$ & $345^{\mathrm{a}}$ & $791^{\mathrm{d}}$ \\
$\quad$ SE & 6.0 & 3.0 & 1.8 & 2.1 \\
Stem & & & & \\
Anthesis & $108^{\mathrm{a}}$ & $700^{\mathrm{b}}$ & $427^{\mathrm{b}}$ & $646^{\mathrm{a}}$ \\
Anthesis + 10 day & $88^{\mathrm{b}}$ & $746^{\mathrm{a}}$ & $455^{\mathrm{a}}$ & $542^{\mathrm{b}}$ \\
$\quad$ SE & 4.4 & 4.5 & 4.4 & 7.0 \\
Inflorescence & & & & $701^{\mathrm{a}}$ \\
Anthesis & $194^{\mathrm{a}}$ & $599^{\mathrm{b}}$ & $322^{\mathrm{b}}$ & $592^{\mathrm{b}}$ \\
Anthesis + 10 day & $157^{\mathrm{b}}$ & $644^{\mathrm{a}}$ & $348^{\mathrm{a}}$ & 4.1 \\
$\quad$ SE & 2.4 & 2.4 & 3.1 &
\end{tabular}

${ }^{1}$ Means within a tissue type and chemical component with different superscripts differ at $\mathrm{P}<0.05$.

Diploid and tetraploid annual ryegrass (Lolium multiflorum Lam.) did not differ in $\mathrm{CP}$ content, but tetraploids had lower NDF concentrations, probably because they matured later than diploid plants (Nelson and Rouquette, Jr. 1983). In perennial ryegrass (perenne $\mathrm{L}$.), relative feed value of tetraploids ranked higher than diploids in first-cut material, while ploidy levels did not differ in second cut material (Casler 1990). In other perennial ryegrass research, tetraploid cultivars were more digestible with higher concentrations of CP, and digestible NDF and lower NDF values than diploid cultivars (Jensen et al. 2003). Results from studies on annual and perennial ryegrass indicate rather small and inconsistent forage quality affects due to ploidy level, which generally support our results with Russian wildrye. In general, there are more forage quality differences between than within species.

\section{Water Treatment}

Russian wildrye leaf and stem tissue from plants grown at the $50 \%$ water treatment had higher CP and IVDMD, and lower ADF and NDF, than plants grown at the $150 \%$ treatment. Soil water potential measurements taken during this study and previously published (Frank and Berdahl 2001 ), confirm that plants grown at $50 \%$ of average precipitation were under greater water stress at both 10 and $134 \mathrm{~kg}$ $\mathrm{N} \mathrm{ha}^{-1}$, than plants grown at $150 \%$. Water stressed crested wheatgrass, smooth bromegrass and Altai wildrye plants demonstrated an increased rate in the seasonal decline of $\mathrm{N}$ and phosphorus, probably due to increased leaf senescence, but drought reduced the seasonal decline in digestibility (Bittman et al. 1988). In con- trast to these results, Jensen et al. (2003) found that water stress uniformly increased $\mathrm{CP}$ in orchardgrass and perennial ryegrass, and the authors concluded that as water stress increased forage nutritional value increased. The affect of water stress on orchardgrass and perennial ryegrass support our results with Russian wildrye. However, water stress produced just the opposite effect on kleingrass, a warm-season specie, as water stress increased, leaf and stem IVDOM decreased (Pittman et al. 1981). Water stress affects on kleingrass were apparently due to an increased proportion of cell wall components and increased lignification (Pitman et al. 1983). With green panic (Panicum maximum var. trichoglume), also a warm-season grass, water stress had no affect on cell wall content or $\mathrm{N}$ in specific leaves, but decreased IVDMD when comparisons were made at a common physiological age (Wilson and Ng 1975). Green panic stems at a common physiological age were similar in cell wall content and IVDMD between water-stressed and non-stressed plants. The IVDMD of water-stressed green panic, buffel (Cenchrus ciliaris L. ), and spear grass (Heteropogon contortus L.) was generally similar or higher than normally watered plants (Wilson 1983). When leaf IVDMD was higher in waterstressed plants, it was usually because IVDMD declined more slowly as the water-stressed plants matured. Stem development was slowed in water-stressed grasses, which likely resulted in higher IVDMD compared to normally watered plants (Wilson 1983). Forage maize (Zea mays L.), a warm-season grass, had lower NDF and higher IVDMD when grown in a dry compared to a wet season (Crasta and
Cox 1996). The inconclusive nature of water stress effects on both cool and warm-season grass nutritive quality sug. gest that numerous changes may occur in plant morphology and physiology, some having positive and some negative effects on forage quality.

Water stress effects on alfalfa have been inconsistent. Halim et al. (1989) reported that water stress in alfalfa at the bud or flower stage reduced the leaf-to-stem ratio (LSR) and IVDMD, but water stress at the vegetative stage did not affect the LSR or IVDMD. Crude protein was increased in water-stressed alfalfa stems, but decreased in leaves. The decline in alfalfa forage quality due to water stress at the bud or flower stages was caused by a reduction in LSR and deterioration in leaf quality (Halim et al. 1989). Water-stressed birdsfoot trefoil (Lotus corniculatus L.), cicer milkvetch (Astragalus cicer L.), red clover (Trifolium pratense L.), and alfalfa produced forage with lower ADF, NDF, and ADL (Peterson et al. 1992). Improved quality in water-stressed legumes was related to greater LSR, delayed maturity, and higher quality in both leaf and stem fractions. The nutritive quality response of these legumes to water stress was similar to our results with Russian wildrye.

\section{Nitrogen Fertilizer}

In our research, $\mathrm{N}$ fertilizer had a positive effect on Russian wildrye leaf, stem, and inflorescence forage quality. Similar positive effects of $\mathrm{N}$ fertilizer on $\mathrm{CP}$ and IVDMD have been reported in warm-season grasses (Perry and Baltensperger 1979). It has also been reported that organic matter digestibility (OMD) and $\mathrm{N}$ concentration in crested wheatgrass, Altai wildrye (Leymus angustus (Trin.) and Russian wildrye forage were increased by $\mathrm{N}$ fertilizer (Lawrence and Knipfel 1981, Lawrence et al. 1982). In other research Holt et al. (1991) indicated that $\mathrm{N}$ fertilizer only marginally increased Russian wildrye $\mathrm{N}$ and $\mathrm{OMD}$ in the early season. Forage maize quality was improved with each additional increment of $\mathrm{N}$ fertilizer (Cox et al. 1993).

Although leaf, stem, and inflorescence tissue quality components were not statistically compared, it is apparent that leaf tissue had the highest quality followed by inflorescence and stem tissue. In vivo dry matter digestibility of leaf tissue of five tropical grasses by sheep was slightly lower than stem tissue (Laredo and Minson 1973). Annual rye (Secale cereale L.), soft red winter wheat (Triticum aestivum L.), oat (Avena sativa L.), and triti- 
cale ( $X$ Triticosecale Wittm.) differed in leaf and stem IVDMD, with oat having the lowest stem IVDMD, but the highest leaf IVDMD (Bruckner and Hanna 1990).

\section{Harvest Date}

Russian wildrye leaf, stem, and inflorescence tissue quality were all negatively affected by maturity in our research, indicating that maturity affects were not just due to a decline in the LSR or to the presence of reproductive tillers, but to an actual decline in tissue quality. Warm-season grass leaf IVDMD was also reported to decline throughout the season. The primary cause for declining warm-season grass quality was tissue aging rather than advancing morphological stage (Perry and Baltensperger 1979, Hendrickson et al. 1997).

\section{Conclusion}

Ploidy level differences in Russian wildrye forage quality were rather small and inconsistent, indicating that in the breeding and selection process for improved seedling emergence, forage quality in the new tetraploid germplasm was not adversely affected. Water stress resulted in significant improvements in leaf and inflorescence tissue quality, but only $\mathrm{CP}$ was affected in stem tissue. Although yield would likely be negatively affected by water stress, improvements in leaf and inflorescence quality should partially compensate for the adverse affects of drought. High levels of $\mathrm{N}$ fertilizer positively affected leaf, stem, and inflorescence tissue quality which would be a bonus to anticipated improvements in dry matter yield. As plants increased in maturity forage quality declined, but the decline occurred in all 3 tissues, indicating that the adverse effects of maturity were not simply due to a decrease in the LSR.

This research verifies that Russian wildrye is a high quality forage for spring grazing with $\mathrm{CP}$ in leaf and inflorescence tissue being adequate for most classes of beef cattle even at the anthesis plus 10-day stage of maturity. The development of tetraploid germplasm with improved seedling emergence, and forage quality comparable to diploid Russian wildrye, provides Northern Great Plains producers with another cool-season grass for reseeding deteriorated grasslands.

\section{Literature Cited}

Baron, V.S., A.C. Dick, and J.R. King. 2000. Leaf and stem mass characteristics of coolseason grasses grown in the Canadian parkland. Agron. J. 92:54-63.

Berdahl, J.D. and R.E. Barker. 1991. Characterization of autotetraploid Russian wildrye produced with nitrous oxide. Crop Sci. 31:1153-1155.

Berdahl, J.D. and R.E. Ries. 1997. Development and vigor of diploid and tetraploid Russian wildrye seedlings. J. Range Manage. 50:80-84.

Bittman, S., G.M. Simpson, and Z. Mir. 1988. Leaf senescence and seasonal decline in nutritional quality of three temperate forage grasses as influenced by drought. Crop Sci. 28:546-552.

Bruckner, P.L. and W.W. Hanna. 1990. In vitro digestibility of fresh leaves and stems of small-grain species and genotypes. Crop Sci. 30:196-202.

Buxton, D.R. and G.C. Marten. 1989. Forage quality of plant parts of perennial grasses and relationship to phenology. Crop Sci. 29:429-435.

Casler, M.D. 1990. Cultivar and cultivar $x$ environment effects on relative feed value of temperate perennial grasses. Crop Sci. 30:722-728.

Cox, W.J., S. Kalonge, D.J.R. Cherney, and W.S. Reid. 1993. Growth, yield, and quality of forage maize under different nitrogen management practices. Agron. J. 85:341-347.

Crasta, O.R. and W.J. Cox. 1996. Temperature and soil water effects on maize growth, development, yield, and forage quality. Crop Sci. 36:341-348.

Ferdinandez, Y.S.N. and B.E. Coulman. 2001. Nutritive values of smooth bromegrass, meadow bromegrass, and meadow $\mathrm{x}$ smooth bromegrass hybrids for different plant parts and growth stages. Crop Sci.41:473-478.

Frank, A.B. and J.D. Berdahl. 1999. Soil and water use by diploid and tetraploid Russian wildrye. Crop Sci. 39:1101-1106.

Frank, A.B. and J.D. Berdahl. 2001. Gas exchange and water relations in diploid and tetraploid Russian wildrye. Crop Sci. 41:87-92.

Goering, H.K. and P.J. Van Soest. 1970. Forage fiber analyses. USDA Agr. Handb. No. 379.

Halim, R.A., D.R. Buxton, M.J. Hattendorf, and R.E. Carlson. 1989. Water-deficit effects on alfalfa at various growth stages. Agron. J. 81:765-770.

Hendrickson, J.R., L.E. Moser, K.J. Moore, and S.S. Waller. 1997. Leaf nutritive value related to tiller development in warm-season grasses. J. Range Manage. 50:116-122.
Holt, N.W., R.P. Zentner, T. Lawrence, M.R. Kilcher, and H. Peters. 1991. Effect of nitrogen fertilizer on beef production and forage quality of Russian wildrye. Can. J. Anim. Sci. 71:833-843.

Jensen, K.B., B.L. Waldron, K.H. Asay, D.A. Johnson, and T.A. Monaco. 2003. Forage nutritional characteristics of orchardgrass and perennial ryegrass at five irrigation levels. Agron. J. 95:668-675.

Johnson, J.R. and J.T. Nichols. 1970. Plants of South Dakota Grasslands- a photographic study. Bull. 566, Agr. Exp. Sta., South Dakota State University. Brookings, S.D.

Kilcher, M.R. 1975. Contribution of leaves and stems to the yield and quality of Russian wild ryegrass and altai wild ryegrass. Can. J. Plant Sci. 55:1029-1032.

Kilcher, M.R. and J.E. Troelsen. 1973. Contribution of stems and leaves to the composition and nutrient content of irrigated bromegrass at different stages of development. Can. J. Plant Sci. 53:767-771.

Laredo, M.A. and D.J. Minson. 1973. The voluntary intake, digestibility, and retention time by sheep of leaf and stem fractions of five grasses. Aust. J. Agr. Res. 24:875-888.

Lawrence, T. 1963. A comparison of methods of evaluating Russian wild ryegrass for seedling vigor. Can. J. Plant Sci. 43:307-312.

Lawrence, T. and J.E. Knipfel. 1981. Yield and digestibility of crested wheatgrass and Russian and Altai wild ryegrasses as influenced by $\mathrm{N}$ fertilization and date of first cutting. Can. J. Plant Sci. 61:609-618.

Lawrence, T., G.E. Winkleman, and F.W. Warder. 1982. The chemical composition of Russian and altai wild ryegrass and crested wheatgrass as influenced by $\mathrm{N}$ fertilization and date of harvest. Can. J. Plant Sci. 62:373-390.

Lawrence, T., A.E. Slinkard, C.D. Ratzlaff, N.W. Holt, and P.G. Jefferson. 1990. Tetracan, Russian wild ryegrass. Can. J. Plant Sci. 70:311-313.

Mowat, D.N., R.S. Fulkerson, W.E. Tossell, and J.E. Winch. 1965. The in vitro digestibility and protein content of leaf and stem portions of forages. Can. J. Plant Sci. 45:321-331.

Nelson, L.R. and F.M. Rouquette, Jr. 1983. Neutral detergent fiber and protein levels in diploid and tetraploid ryegrass forage. Proceedings of the XVI International Grassland Congress. Lexington, Ky. 1981. Edited by J.A. Smith and V.W. Hays. Westriew Press, Boulder, Colo. pp. 234-237.

NRC. 1996. Nutrient Requirements of Domestic Animals. Nutrient Requirements of Beef Cattle. 7th Edition. National Academy Press, Washington, DC. 
Perry, L.J., Jr. and D.D. Baltensperger. 1979. Leaf and stem yields and forage quality of three $\mathrm{N}$-fertilized warm-season grasses. Agron. J. 71:355-358.

Peterson, P.R., C.C. Sheaffer, and M.H. Hall. 1992. Drought effects on perennial forage legume yield and quality. Agron. J. 84:774-779.

Pitman, W.D., D.M. Vietor, and E.C. Holt. 1981. Digestibility of kleingrass forage grown under moisture stress. Crop Sci. 21:951-953.
Pitman, W.D., E.C. Holt, B.E. Conrad, and E.C. Bashaw. 1983. Histological differences in moisture-stressed and nonstressed kleingrass forage. Crop Sci. 23:793-795.

Pritchard, G.I., L.P. Folkins, and W.J. Pigden. 1963. The in vitro digestibility of whole grasses and their parts at progressive stages of maturity. Can J. Plant Sci. 43:79-87.

Ries, R.E. and L. Zachmeier. 1985. Automated rainout shelter for controlled water research. J. Range Manage. 38:353-357.
SAS. 1996. SAS System for mixed models. SAS Inst., Inc. Cary, N.C.

Vogel, K.P., J.F. Pedersen, S.D. Masterson, and J.J. Toy. 1999. Evaluation of a filter bag system for NDF, ADF, and IVDMD forage analysis. Crop Sci. 39:276-279.

Wilson, J.R. 1983. Effects of water stress on in vitro dry matter digestibility and chemical composition of herbage of tropical pasture species. Aust. J. Agr. Res. 34:377-390.

Wilson, J.R. and T.T. Ng. 1975. Influence of water stress on parameters associated with herbage quality of Panicum maximum var. trichoglume. Aust. J. Agr. Res. 26:127-136.

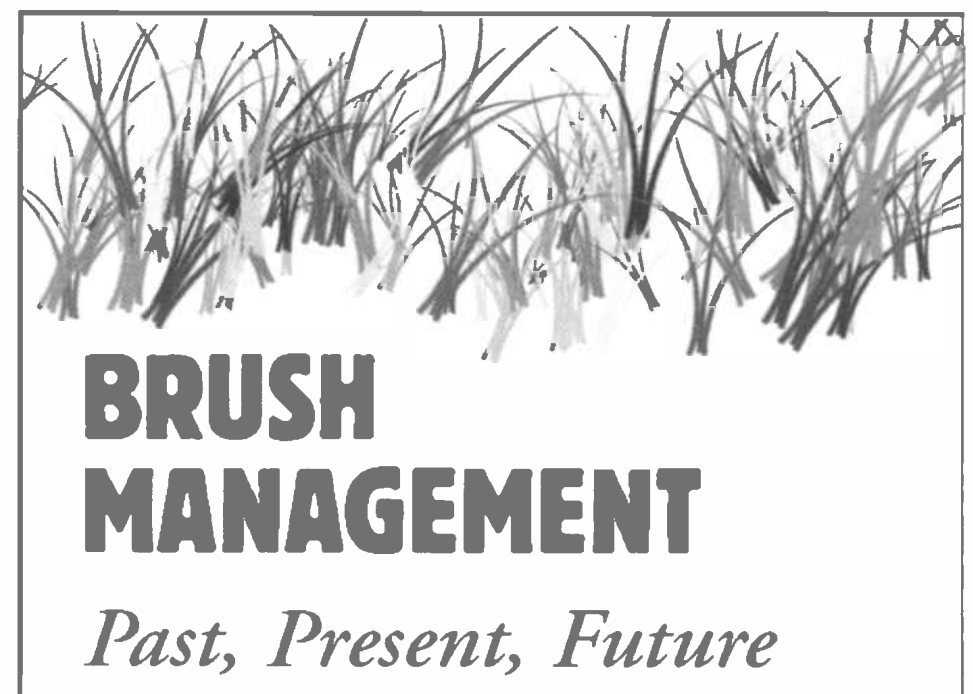

\section{Wayne T. Hamilton, Allan McGinty, Darrell N. Ueckert, C. Wayne Hanselka, and Michelle R. LeE}

In the pages of this book, leading range management professionals introduce and explain not only the mechanisms of managing brush but also the changes in management philosophy and technology that have taken place over time. From the futile attempts at eradication to the successes of integrated brush management, practitioners examine mechanical, biological, chemical, and fire-related methods from three perspectives-the past, the present or "state-of-the-art," and the future. In a final discussion, three specialists address the timely and important subject of brush management as it relates to water yield, economics, and wildlife.

$81 / 2 \times 11.288$ pp. 45 b\&w photos. 15 line drawings. 23 tables. $\$ 50.00$ cloth; $\$ 26.00$ paper

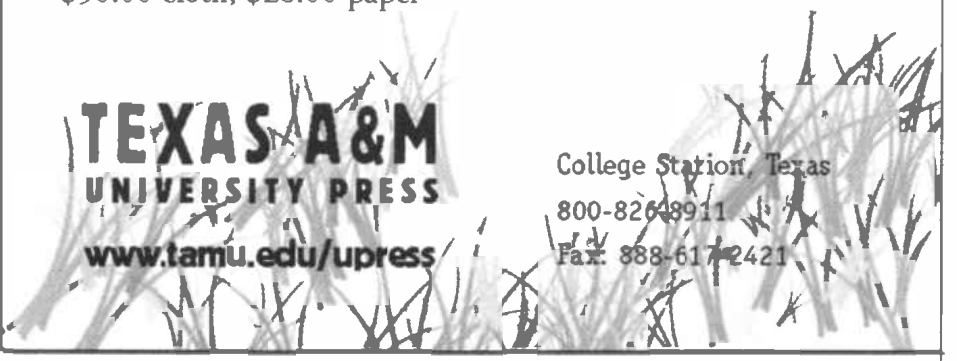

